This item was submitted to Loughborough's Research Repository by the author.

Items in Figshare are protected by copyright, with all rights reserved, unless otherwise indicated.

\title{
Boundary-crossing academic mobilities in glocal knowledge economies: new research agendas based on triadic thought
}

PLEASE CITE THE PUBLISHED VERSION

https://doi.org/10.1080/14767724.2017.1413977

\section{PUBLISHER}

(C) Taylor \& Francis (Routledge)

\section{VERSION}

AM (Accepted Manuscript)

\section{PUBLISHER STATEMENT}

This work is made available according to the conditions of the Creative Commons Attribution-NonCommercialNoDerivatives 4.0 International (CC BY-NC-ND 4.0) licence. Full details of this licence are available at: https://creativecommons.org/licenses/by-nc-nd/4.0/

\section{LICENCE}

CC BY-NC-ND 4.0

\section{REPOSITORY RECORD}

Jons, Heike. 2019. "Boundary-crossing Academic Mobilities in Glocal Knowledge Economies: New Research Agendas Based on Triadic Thought". figshare. https://hdl.handle.net/2134/28012. 
For published version, see:

https://doi.org/10.1080/14767724.2017.1413977

Boundary-crossing academic mobilities in glocal knowledge economies:

new research agendas based on triadic thought

GSE special issue introduction

28 November 2017

Dr Heike Jöns

Reader in Human Geography

Department of Geography

Loughborough University

Loughborough LE11 3TU

United Kingdom

Phone +44 (0) 1509228199

H.Jons@lboro.ac.uk 


\section{Abstract}

This editorial introduction identifies a need for more multidimensional and collective theorisations of boundary-crossing academic mobilities in order to conceptualise this phenomenon, compare empirical findings, and identify new research perspectives. My suggestion is that triadic thought - or the thinking in three rather than two conceptual categories - overcomes some of the limitations that binary thought has imposed on social theory. By transforming the three conceptual dyads that frame this special issue on boundary-crossing academic mobilities, namely mobility/migration, students/academics, and local/global, into more differentiated relational triads, I argue that ordering and framing studies on academic and other mobilities through three-by-three matrices grounded in triadic thought helps to advance conceptual debate and unfold a wider research agenda in truly collective ways.

\section{Keywords}

academic mobility, student migration, higher education, knowledge economy, glocalisation, triadic thought 
Scholars of different disciplinary affiliations have emphasised the need to examine the production, circulation, and use of knowledge, education, and learning through transnationally mobile students, researchers, and other knowledge workers in order to understand the nature, complexities, and contradictions of past, present, and future knowledge economies (e.g., Blumenthal et al. 1996; Smith and Favell 2006; Byram and Dervin 2008; Brooks and Waters 2011; Fechter and Walsh 2012; Alberts and Hazen 2013; Chou, Kamola, and Pietsch 2016; Van Riemsdijk and Wang 2016; Jöns, Heffernan, and Meusburger 2017; Tournés and Scott-Smith 2017). This special issue adds to this wider research agenda by bringing together innovative research perspectives on the mobilities of university students, PhD graduates, academics, and higher education programmes with the threefold aim of developing established foci, presenting novel approaches, and identifying new avenues for future research.

Since education scholar Philip Altbach $(1989,125)$ identified "the new internationalism" of foreign students and scholars, and geographers Allan Findlay and William Gould (1989) sketched their new research agenda on skilled international migration, three distinct lines of research have studied the transnational mobility of students (e.g., Li et al. 1996; King and Ruiz-Gelices, 2003; Findlay et al. 2006, 2012; Waters 2006, 2012; Holloway et al. 2012; Collins 2013; King and Raghuram 2013; Waters and Leung 2013; Beech 2014; van Mol 2014; Prazeres 2016; Basford and van Riemsdijk 2017), scientists and scholars (e.g., Heffernan 1994; Jöns 2003, 2015; Ackers 2005, 2010; Kim 2009; Robertson 2010; Leung 2012; Larner 2015; Bauder 2015; Cañibano, Fox, and Otamendi 2016; Storme et al. 2017), and skilled professionals in high tech industries (e.g., Saxenian 2006; Van Riemsdijk 2014), advanced producer services (e.g., Beaverstock 2017; Cranston et al. 2017), and creative fields (e.g., Boren and Young 2013; Ibert and Schmidt 2014). 
This introduction situates the research foci of the five contributions to this special issue within a broader research agenda on academic mobilities, understood in the widest possible sense as spatial movements linked to universities, involving people and organisms, technologies and material things, knowledge and practices, imaginations and representations, communications and virtual information (Harvey 2005, 105; Urry 2007, 47; Jöns, Heffernan, and Meusburger 2017, 5). Situated within this wider agenda, this special issue joins research on the three established lines of people-centred inquiries with the mobility of institutional provisions by discussing inter-regional mobility for university education from Scotland to England (Findlay et al. 2017); international mobility of students from the UK and India (King and Sondhi 2017); international branch campuses as regional hubs of international study in South Africa (Gunter and Raghuram 2017); and international knowledge transfer (Coey 2017) as well as intersectoral mobilities (Millard 2017) of European PhD graduates in the social sciences and humanities.

In the following, I build on the convincing critique by geographer Russell King (2002, 89) of "the old dichotomies of migration study" - such as mobility/migration, internal/international, and temporary/permanent-to develop the twofold argument that there is a need for more multidimensional and collective theorizations of academic mobilities and migration, and that such theorizations could be enriched by replacing some of the restrictive dyads of dualistic thinking through more diverse but still manageable triads of triadic thought. In other words, I aim to illustrate how attempts to compare the empirical findings of a proliferating number of empirical case studies on academic mobilities - to understand the studies' respective viewpoints, discuss their context-specific intellectual contributions, and sketch new research agendas-could benefit from using three rather than two conceptual categories-or triads rather than dyads-because triadic thought accounts 
for a greater variety of increasingly complex research perspectives, while still providing manageable and comprehensible conceptual orderings (Jöns 2006; Dawson and Jöns 2017).

\section{Defining triadic thought}

Triadic thought can be defined as conceptual thinking in three thematically related categories that constitute either a continuum between two extreme possibilities, in which the third category represents a logical middle ground, or a non-reducible triad that can neither be expressed in two categories because there is no logical middle ground nor be reduced to two categories without blurring key ontological differences between two of the three categories. Despite his previous scepticism towards binary opposites, King $(2012,137)$ has recently emphasised that such binaries are "compromised by the blurred reality" of migration, yet "they remain heuristically useful to define the opposite poles of spectra along which ... migratory situations can be positioned." This observation suggests that acknowledging the middle ground of such spectra as a third conceptual category represents a first viable strategy for capturing the growing diversity and complexity of studies on academic mobilities. Examples for triadic continua are (1) short-term/medium-term/longterm mobilities; (2) micro/meso/macro scales; and (3) early/mid/late career stages.

A second strategy to enhance more differentiated theorising is represented by nonreducible triads resulting from the insight that not all binaries of social theory are opposite poles of spectra. Some binary categories are either linked by a third, ontologically different category, or represent three non-reducible categories altogether. For instance, my own research generated a conceptual "trinity of actants", a notion that transformed actornetwork theory's binary of humans and nonhumans into a more symmetrical triad of materialities, humans and other "dynamic hybrids", and immaterialities as three rather than 
two types of entities that shape network-building processes (Jöns 2001, 2003, 2006). The first conceptual move to arrive at the trinity of actants integrated the research foci of social constructivism and actor-network theory, which were strongly debated in the late 1990s, by acknowledging that both immaterial entities - as stressed in social constructivist studies about the role of prior knowledge, interests, and beliefs in scientific knowledge production (Bloor 1999) - and material entities - as represented by actor-network theory's emphasis on non-human material resources (Latour 1999a) — need to be distinguished in conceptual debates because they both shape academic mobilities for knowledge production, albeit in very different ways.

In short, research practices involving distant and place-specific materialities, technologies, and human environments that cannot be moved easily or at all-as frequently encountered by field workers in the geological, physical, and anthropological sciencesrequire access to specific places at least once through trans/national mobility, whereas those research practices primarily based on reading and thinking-as in some areas of the mathematical, theoretical, and philosophical sciences - are less bound to particular places and thus could either be undertaken at home or anywhere else where the researcher/s would feel comfortable (Jöns 2006, 2007). In this special issue, Coey (2017) elaborates how such subject-specific differences shape the mobilities of researchers and academics, whereas Millard's (2017) findings show that intersectoral mobilities between universities and the private, public, and third sectors vary considerably by different types of more or less context- and place-specific academic knowledges and thus by disciplines.

The second conceptual argument that transformed the binary of human and nonhumans into a trinity of actants drew on Lefebvre's $(1991,406-407)$ insistence on the "unification of subject and object" in the "living body" when arguing that the geographically 
relevant ontological difference between im/materialites can only be bridged by entities whose "abilities are based on a dynamic combination of both realms" (Jöns 2006, 571). Such "dynamic hybrids", like humans, other organisms, and intelligent machines, are characterised by "a continuous circulation providing a dynamic connection between their material, immaterial and dynamically hybrid components" (573), which enables themthrough practices - to transform matter into meaning and meaning into matter-something neither ideas nor rocks can do. The notion of dynamic hybrids thus acknowledges that many non-human organisms, cyborgs, and other technologies have more in common with humans than with non-dynamic im/materialities because they are capable of conducting practices and thus are actively creating experiences and learning processes. In the grand narratives of social theory, dynamic hybrids bridge the gap/s between "the world" and "words about the world" - or between matter and form-, a divide Latour (1999b, 193) called "the modernist settlement", in which "objects were housed within nature and subjects within society." ii

The notion of a trinity of actants has been discussed in different empirical contexts, such as changing geographies of Hungarian banking (Jöns 2001), the nature, geographies, and outcomes of transnational academic mobility in different disciplines and research practices (Jöns 2003, 2006, 2007), performer dance training (Camilleri 2015), robotic technologies (Del Casino 2016), and mega-event legacy theory (Dawson and Jöns 2017). In the context of boundary-crossing academic mobilities, the concept suggests three broader research perspectives, namely (1) the agency, movement, and interaction of people and other dynamic hybrids; (2) their ideas, imaginations, and emotions; and, as Gunter and Raghuram (2017) stress in this special issue, (3) the wide range of materialities that constitute research, teaching, and learning (Table 1). 
[Please insert Table 1 about here]

The remainder of this introduction discusses the value of triadic thought for conceptualising academic mobilities, comparing the findings of empirical case studies, and identifying new research perspectives. My focus will be on the question of how the three conceptual dyads of analysis that frame this special issue-mobility/migration, students/staff, and local/global-can usefully be transformed into more differentiated relational triads. Reference will be made to Table 2 that locates the main research foci of the contributions to this special issue in relation to each other by differentiating three career stages of mobile skilled people-from entry into higher education to a mature professional career-and three geographical scales-from local via regional to global research perspectives-that characterise the five articles' main analytical approach to "glocal" academic mobilities.

[Please insert Table 2 about here]

\section{Applying triadic thought}

The first binary that unites the contribution to this special issue but has troubled migration scholars for decades is that of mobility/migration (King 2002). Building upon previous multidimensional conceptualisations of mobility/migration, as presented by geographer Tony Fielding $(2012,5)$ with the juxtaposition of intra-regional/inter-regional/international movements and durations of stay ranging from 1 hour to 100 years, I suggest capturing some of the commonalities and differences between typical forms of academic mobilities in a three-by-three matrix of two different triads. Such conceptual ordering through three-by- 
three matrices has previously been pursued by Marxist geographer David Harvey $(2005,105)$ -for outlining the nuances between different spatialities in an attempt to clarify "the range of meanings that attach to the word 'space'" (93)-, and can therefore be regarded as a useful methodological tool (see also note i). Cross-tabulating two triads provides indeed the advantage of opening up nine thematically different fields that enable the visualisation of many more variations between ever more diversifying research foci than the four fields resulting from cross-tabulating dyads would allow for.

One pair of triads that has proven useful for defining mobility/migration is constituted by the differentiation of movements that are linear, circular, or reciprocal (with $A$ and $B$ being variably defined as place of work, education, and/or residence) and shortterm, medium-term, and long-term (Jöns 2003, 9). Accordingly, Table 3 shows that students' credit and degree mobilities vary more by the direction rather than the duration of movement because for the period of one year students can both undertake a Master's degree (Rienties, Luchoomun and Tempelaar 2014) and embark on Erasmus+ study abroad (van Mol 2014). Furthermore, it becomes evident that short-term commuting between different work places (e.g., a research institution and university in the same city) differs conceptually from medium- and longer-term transnationalism and diaspora (e.g., in the case of professorships at two or more universities in different countries; see Larner 2015) through the time period involved, while it shares the same direction of movement and thus potentially other features, too. Positioning research foci within three-by-three matrices can also help to understand that some argumentative differences might be linked to varying research perspectives.

[Please insert Table 3 about here] 
The second traditional dyad of research on academic mobilities that frames this special issue, namely students and academic staff (Altbach 1989; Blumenthal et al. 1996), can be transformed from a life course perspective into the relational triad of skilled people at the early, mid, and late stages of their higher education training and subsequent professional careers (Findlay et al. 2012; Bauder 2015). While the contexts and requirements of international mobility/migration from the perspectives of higher education students, university graduates, researchers and academics may substantially differ-and thus explain largely separate bodies of work-, this special issue includes a much needed comparative perspective about the recruitment of academic staff and students on international branch campuses (Gunter and Raghuram 2017). Linking the literatures on the mobilities of students and academics more frequently could also inspire new conceptual and empirical perspectives that have been employed in "the other" field and thus can serve as a point of reference for fleshing out commonalities and differences (for Bourdieu's forms of capital, see Waters 2006; 2012; Leung 2012; Bauder, Hannan, and Lujan 2017).

Classifying the life course trajectory of skilled people into three main stages not only bridges skilled people's higher education and employment but also has the added advantage of acknowledging more prominently, as Bilecen and Faist (2015) have recently done, that doctoral students (and postdoctoral researchers) represent an intermediate category of skilled people with their own needs and requirements but have hitherto often been overlooked in the dichotomy of university students and academic staff. In the relational spirit of triadic thought, the differentiation of early/mid/late career could also be applied to either students or researchers and academics, thus enabling a more nuanced understanding of mobility needs and challenges at different career stages, for example, between Bachelor's and Master's students. In each case, three categories seem to be more complex and 
inclusive than two for ordering a proliferating number of case studies and their contextspecific findings.

The third conceptual boundary bridged by the case studies of this special issue is that of academic mobilities at different geographical scales. All contributions to this special issue stress the need to consider the co-production of local and global processes and practices in transnational education and careers to underline the "glocal" nature of highly differentiated knowledge economies. Building on a long-standing awareness that "certain translocal cultures can be provincial, while cosmopolitanism is often rooted in the local culture of a city" (Bender 1988, 6), the highly successful concept of "glocalisation" - originally developed by Robertson (1992) and Swyngedouw (1992) in the early 1990s-moves "beyond the basic dichotomization of the local and the global, to explore their mutual interdependency and copresence" as well as "the growing complexity of scales of contemporary political governance, between the international/global, the national, and the subnational/local" (Giulianotti and Robertson 2012, 434).

Building on this integrative nature of the notion "glocalisation", or what the geographer Doreen Massey $(1991,28)$ persuasively called "a sense of place which is extroverted, which includes a consciousness of its links with the wider world, which integrates in a positive way the global and the local," it seems to be useful to acknowledge that the middle ground of a variety of regional scales between the local and the global makes a difference in empirical studies of academic mobilities. For example, van Mol (2014) embedded his analysis of how students from six European countries decided either to participate in the Erasmus programme or to continue their studies in the home university explicitly within macro/meso/micro approaches to migration. He found that some students take the macro economic conditions at home and abroad as much into consideration in their 
decision-making as institutional programme structures, their social environment, and personal development goals. Differentiating the three scales of local, regional, and global research perspectives - or micro/meso/macro scales-also seems to be very practical for capturing the great variety of viewpoints in this special issue because this triadic approach emphasizes the existence of different regional scales within the local-global dichotomyfrom the sub-national region via the nation state to supranational perspectives.

\section{Contributions and outlook}

Findlay et al.'s (2017) contribution to this special issue researches the destination choices of Scottish students studying for their whole degree in England despite tuition fees of $£ 27,000$, which they would not have to pay at Scottish universities. Given that England and Scotland are countries within the sovereign state of the United Kingdom, Findlay et al. (2017) explore the underresearched middle ground between students' international and internal access to English universities in the form of inter-regional student mobility. The authors' qualitative and quantitative research findings reveal that in their decision-making, Scottish students negotiate the material realities of tuition fees (seen as an investment, not a cost) and geographical distance (many choose an English university close to home) with imagined realities about the reproduction of cultural, social, and symbolic capital (in highly ranked English universities) and the identification of suitable springboards for international careers (such as Oxbridge and London-based universities). Accordingly, Findlay et al. (2017) argue that inter-regional student mobility from Scotland to England displays both features of international student mobility linked to globalisation (e.g., desired international career path) and internal student mobility shaped by local specificities (e.g., available degree programmes) and an interest to be close to home. This key finding reflects the conceptual 
middle position of inter-regional student mobility but also identifies this specific type of movement as a profoundly distinct phenomenon.

King and Sondhi's (2017) article presents an innovative comparative analysis of motivations for study abroad among students from India and the UK. By comparing international degree mobility between two home countries and several host countries, the authors' global research approach presents a much needed comparison of global north and global south perspectives in international student mobility. Based on surveys and interviews, the authors find striking similarities in regard to the social background of the mobile students, thus identifying international students from different world regions as part of the transnational capitalist class (Robinson and Harris 2000; Findlay et al. 2012). Similarities are also more prominent than differences in regard to the students' motivations for study abroad because both UK and Indian students (and also those of different genders) were motivated to move abroad by the attraction of world-class universities; access to an international career; the experience of adventure; and family encouragement. Subtle differences result from the global positionality of the students' home countries and thus reveal complex configurations of brain drain/circulation/gain that underline how international flows of students can both reinforce and change global power-relations.

Gunter and Raghuram's (2017) investigation of knowledge mobilities in the global south accesses global higher education through the local perspective of three international university branch campuses in South Africa. Based on a survey among academic staff and an examination of the historical context, the authors' novel integrative perspective on academic staff, students, knowledge, and infrastructures reveals how international higher education provision from Australia, the Netherlands, and the UK has tapped into a regional demand by students from the Southern African Development Community (SADC), who are 
often unable to access the more renowned South African research universities but wish to benefit from Westernised international higher education without leaving Africa. Gunter and Raghuram's (2017) findings highlight that these internationalised higher education hubs for the wider SADC region are shaped by a regionalisation of staff and student recruitment and a localisation of course content. Conceptually, this means that the nature of international branch campuses is mediated by global power-relations, regional geopolitics, and local historical-geographical contexts and requires a triadic differentiation of macro/meso/micro scales because the international (e.g., Australia), regional (SADC), and local (in this case South African) dimensions of higher education can play very different roles in regard to the infrastructures, people, and ideas that constitute such knowledge hubs.

The regionalisation of European higher education and research (Robertson et al. 2016) was a key policy aim that motivated the studies by Coey (2017) and Millard (2017) on the population, careers, mobilities, and impacts of PhD graduates in the social sciences and humanities (SSH) from 13 European countries as part of the FP7-funded research project POCARIM. iii By comparing the experiences of European SSH PhD graduates with transnational mobility and knowledge transfer up to thirteen years after the award of their doctoral degrees, Coey's (2017) contribution discusses the rarely addressed topic of international knowledge transfer and exchange through researcher mobility. Applying a relational understanding to short-term/medium-term/longer-term stays abroad, the author identifies three main outcomes resulting from stays of one month to three years, namely the exchange of explicit subject-specific knowledge; the adaptation of tacit scientific and cultural knowledge practices; and the development of a cosmopolitan habitus. Coey's (2017) findings illustrate why personal experience abroad remains essential in order to participate in international (instead of only national) scientific communities of practice; how barriers to 
international mobility - either for return or subsequent mobility-emerge through socialization in the language and culture of one specific PhD country; and that the variations of knowledge outcomes by disciplines warrant further research.

Millard's (2017) qualitative analysis scrutinizes intersectoral moves of European SSH PhD graduates between higher education, private business, the government, NGOs, and other sectors-another topic that has rarely been discussed previously despite growing numbers of PhD graduates and their moves out of academia. Drawing upon Murray's (2010) analytical frame of hostile, co-existing, and blended worlds between academia and other sectors of the economy that result from different knowledge cultures, institutional norms, and career structures, she finds that intersectoral moves and dual roles are often perceived to be easier to undertake within more applied disciplines of economics and law than in sociology and human geography. Knowledge and skills learned in economics and law seem to be epistemologically more compatible with the business world than in sociology and human geography, fields in which more context- and place-specific empirical knowledge eases moves into public or third sector jobs and provides more critical views towards unregulated private sector capitalism that seem to be particularly valued in government service and NGOs. Millard's (2017) geographical comparison confirms that intersectoral moves are more typical for those who stay within their PhD country than for those who are internationally mobile because international mobility among European SSH PhD graduates is often a distinct strategy for securing a job within academia (Jöns and Deakin 2014, 11-12). In comparison, the five contributions to this special issue respond to recent research agendas by analysing mobility systems at different geographical scales (King and Skeldon 2010); providing a range of comparative perspectives, including the global north and the global south (Holloway and Jöns 2012); and attending not only to the socio-cultural (people) 
and epistemological (knowledge) dimensions of international study (Madge et al. 2015) but also to the constitutive material spatialities (resources) of knowledge production and exchange (Raghuram 2013). In addition to the topics mentioned above, I suggest that more empirical research is needed on (1) the mediation of internationalisation processes at different micro/meso/macro scales and in a greater variety of higher education contexts (including Latin America and non-Commonwealth countries in Africa and Asia); (2) institutional (rather than national) cultures of knowledge mobilities and internationalisation (including historical perspectives); (3) knowledge exchange and learning in different disciplines and research practices; (4) the role of other-than-human organisms and diverse technologies-or the great variety of other-than-human dynamic hybrids - in research, teaching, and learning across cultural and political boundaries; (5) comparisons of historical and contemporary knowledge mobilities; and (6) the interplay of different axes of social difference in all of these processes, including gender, race, and linguistic positionality. In conceptual terms, I have aimed to show that ordering and framing future studies by employing three-by-three matrices inspired through triadic thought could (1) enrich comparisons of varying research perspectives; (2) clarify the complexities of multi-scalar knowledge mobilities; and (3) develop new context-specific research perspectives by allowing researchers, as Dawson and Jöns (2017) have argued, to add new triadic subcategories to the debate and combine different triads in novel ways. Arguably, triadic thought can help to overcome some of the limitations imposed on social theory by conceptual thinking operating solely with binary opposites, which have been so powerfully critiqued by philosopher Henri Lefebvre $(1991,407)$ and science studies scholar Bruno Latour $(1993,58)$, yet without moving beyond binary thinking, and especially beyond the Cartesian dualism they originally aimed to overcome. Triadic thought can thus be regarded 
as a new conceptual resource with great potential for more profound understandings of the material, dynamically hybrid, and immaterial dimensions of academic and wider mobilities in different historical and geographical contexts and across multiple axes of social difference.

\section{References}

Ackers, L. 2005. "Moving People and Knowledge: Scientific Mobility in the European Union." International Migration 43 (5): 99-131.

Ackers, L. 2010. "Internationalisation and Equality: The Contribution of Short Stay Mobility to Progression in Science Careers." Recherches Sociologiques et Anthropologiques 41 (1): 83-103.

Alberts, H., and H. Hazen, eds. 2013. International Students and Scholars in the United States: Coming from Abroad. New York: Palgrave Macmillan.

Altbach, P. G. 1989. "The New Internationalism: Foreign Students and Scholars." Studies in Higher Education 14 (2): 125-136.

Basford, S., and M. van Riemsdijk. 2017. "The Role of Institutions in the Student Migrant Experience: Norway's Quota Scheme." Population, Space and Place, in press: doi:10.1002/psp.2005

Bauder H. 2015. "The International Mobility of Academics: A Labour Market Perspective." International Migration 53 (1): 83-96.

Bauder, H., C.-A. Hannan, and O. Lujan. 2017. “International Experience in the Academic Field: Knowledge Production, Symbolic Capital, and Mobility Fetishism." Population, Space and Place, in press: doi:10.1002/psp.2040 
Beaverstock, J. V. 2017. "The Spatial Mobility of Corporate Knowledge: Expatriation, Global Talent, and the World City." In Mobilities of Knowledge, edited by H. Jöns, P. Meusburger, M. Heffernan, 227-246. Cham: Springer.

Beech, S. 2014. "Why Place Matters: Imaginative Geography and International Student Mobility." Area 46 (2): 170-177.

Bender, T. 1988. The University and the City: From Medieval Origins to the Present. Oxford: Oxford University Press.

Bilecen, B., and T. Faist. 2015. “International Doctoral Students as Knowledge Brokers: Reciprocity, Trust and Solidarity in Transnational Networks." Global Networks 15 (2): 217-235.

Bilecen, B., and C. Van Mol. 2017. "Introduction: International Academic Mobility and Inequalities." Journal of Ethnic and Migration Studies 43 (8): 1241-1255.

Bloor, D. 1999. "Anti-Latour." Studies in History and Philosophy of Science 30: 81-112.

Blumenthal, P., C. D. Goodwin, A. Smith, U. Teichler, eds. 1996. Academic Mobility in a Changing World. London: Jessica Kingsley Publishers.

Borén, T., and C. Young. 2013. "The Migration Dynamics of the "Creative Class": Evidence from a Study of Artists in Stockholm, Sweden." Annals of the Association of American Geographers 103 (1): 195-210.

Brooks, R., and J. Waters, J. (2011). Student Mobilities, Migration and the Internationalization of Higher Education. Basingstoke: Palgrave Macmillan.

Byram, M., and F. Dervin, eds. 2008. Students, Staff and Academic Mobility in Higher Education. Newcastle: Cambridge Scholars.

Camilleri, F. 2015. "Of Hybrids and the Posthuman: Performer Training in the $21^{\text {st }}$ Century." The Drama Review 59 (3): 108-122. 
Cañibano, C., M. F. Fox, and F. J. Otamendi. 2016. “Gender and Patterns of Temporary Mobility among Researchers." Science and Public Policy 43 (3): 320-331.

Chou, M., I. Kamola, and T. Pietsch, eds. 2016. The Transnational Politics of Higher Education: Contesting the Global / Transforming the Local. Abingdon: Routledge.

Coey, C. 2017. "International Researcher Mobility and Knowledge Transfer in the Social Sciences and Humanities." Globalisation, Societies and Education, in press.

Collins, F. L. 2013. “Regional Pathways: Transnational Imaginaries, Infrastructures and Implications of Student Mobility within Asia." Asian and Pacific Migration Journal 22 (4): 475-500.

Cranston, S., J. Schapendonk, and E. Spaan. 2017. "New Directions in Exploring the Migration Industries: Introduction to Special Issue." Journal of Ethnic and Migration Studies, in press: doi:10.1080/1369183X.2017.1315504.

Dawson, J., and H. Jöns 2017. “Unravelling Legacy: A Triadic Actor-Network Theory Approach to Understanding the Outcomes of Mega Events." Journal of Sport and Tourism, under review.

Del Casino, V. J. Jr. 2016. “Social Geographies II: Robots." Progress in Human Geography 40 (6): $846-855$.

Fechter, A.-M., and K. Walsh, eds. 2012. The New Expatriates: Postcolonial Approaches to Mobile Professionals. London: Routledge.

Fielding, T. 2012. Migration in Britain: Paradoxes of the Present, Prospects for the Future. Cheltenham: Edward Elgar.

Findlay, A., and W. T. S. Gould. 1989. "Skilled International Migration: A Research Agenda." Area 21 (1): 3-11. 
Findlay, A.M., R. King, A. Stam, and E. Ruiz-Gelices. 2006. "Ever-Reluctant Europeans: The Changing Geographies of UK Students Studying and Working Abroad." European Urban and Regional Studies 13 (4): 291-318.

Findlay, A. M., R. King, F. M. Smith, A. Geddes, and R. Skeldon 2012. “World Class? An Investigation of Globalisation, Difference and International Student Mobility. Transactions of the Institute of British Geographers 37 (1): 118-131.

Findlay, A., H. Packwood, D. McCollum, G. Nightingale, and Tindal, S. 2017. “Fees, Flows and Imaginaries: Exploring the Destination Choices Arising from Intra-National Student Mobility." Globalisation, Societies and Education, in press.

Giulianotti, R., and R. Robertson, R. 2012. “Glocalization and Sport in Asia: Diverse Perspectives and Future Possibilities." Sociology of Sport Journal 29 (4): 433-454.

Gunter, A., and P. Raghuram. 2017. "International Study in the Global South: Linking Institutional, Staff, Student, and Knowledge Mobilities." Globalisation, Societies and Education, in press.

Harvey. D. 2005. "Space as a key word." In Spaces of Neoliberalization: Towards A Theory of Uneven Geographical Development. Hettner Lecture 2004 with David Harvey, 93-115. Stuttgart: Franz Steiner.

Heffernan, M. 1994. “A State Scholarship: The Political Geography of French International Science during the Nineteenth Century." Transactions of the Institute of British Geographers 19 (1): 21-45.

Holloway, S. L., and H. Jöns. 2012. "Geographies of Education and Learning." Transactions of the Institute of British Geographers 37 (4): 482-488. 
Holloway, S. L., S. L. O’Hara, and H. Pimlott-Wilson. 2012. “Educational Mobility and the Gendered Geography of Cultural Capital: The Case of International Student Flows between Central Asia and the UK." Environment and Planning A 44 (9): 2278-2294. Ibert, O., and S. Schmidt. 2014. "Once You Are in You Might Need to Get Out: Adaptation and Adaptability in Volatile Labor Markets - the Case of Musical Actors." Social Sciences 3 (1): 1-23.

Jöns, H. 2001. “Foreign Banks are Branching Out: Changing Geographies of Hungarian Banking, 1987-1999." In Transformations in Hungary: Essays in Economy and Society, edited by P. Meusburger, and H. Jöns, 65-124. Heidelberg: Physica-Verlag.

Jöns, H. 2003. Grenzüberschreitende Mobilität und Kooperation in den Wissenschaften: Deutschlandaufenthalte US-amerikanischer Humboldt-Forschungspreisträger aus einer erweiterten Akteursnetzwerkperspektive [Boundary-crossing academic mobility and collaboration: Research stays of U.S. Humboldt Award Winners in Germany from an extended actor-network perspective]. (Heidelberger Geographische Arbeiten, Vol. 116). Heidelberg: Selbstverlag des Geographischen Instituts der Universität Heidelberg. Jöns, H. 2006. “Dynamic Hybrids and the Geographies of Technoscience: Discussing Conceptual Resources Beyond the Human/Non-Human Binary." Social and Cultural Geography 7 (4): 559-580.

Jöns, H. 2007. "Transnational Mobility and the Spaces of Knowledge Production: A Comparison of Global Patterns, Motivations and Collaborations in Different Academic Fields." Social Geography 2 (2): 97-114.

Jöns, H. 2015. "Talent Mobility and the Shifting Geographies of Latourian Knowledge Hubs." Population, Space and Place 21 (4): 372-389. 
Jöns, H., and H. Deakin. 2014. Geographies of Transnational Career (Im)mobility of European PhD Graduates in the Social Sciences and Humanities. POCARIM Policy Report 11. Salford: University of Salford.

Jöns, H., M. Heffernan, and P. Meusburger. 2017. “Mobilities of Knowledge: An Introduction." In Mobilties of Knowledge, edited by H. Jöns, P. Meusburger, and M. Heffernan, 1-19. Cham: Springer.

Kim, T. 2009. "Shifting Patterns of Transnational Academic Mobility: A Comparative and Historical Approach." Comparative Education 45 (3): 387-403.

King, R. 2002. "Towards a New Map of European Migration." International Journal of Population Geography 8 (2): 89-106.

King, R. 2012. "Geography and Migration Studies: Retrospect and Prospect." Population, Space and Place 18 (2): 134-153.

King, R., and E. Ruiz-Gelices. 2003. "International Student Migration and the European 'Year Abroad'"'. International Journal of Population Geography 9 (3): 161-181.

King, R., and R. Skeldon. 2010. “'Mind the Gap!' Integrating Approaches to Internal and International Migration." Journal of Ethnic and Migration Studies 36 (10): 1619-1646.

King, R., and P. Raghuram. 2013. "International Student Migration: Mapping the Field and New Research Agendas. Population, Space and Place 19 (2): 127-137.

King, R., and G. Sondhi. 2017. "International Student Migration: A Comparison of UK and Indian Students' Motivations for Studying Abroad." Globalisation, Societies and Education, in press

Kupiszewska, D., M. Kupiszewski, A. Kicinger, L. Ackers, C. Coey. 2013. Mapping the Population, Careers, Mobilities and Impacts of Advanced Research Degree Graduates in 
the Social Sciences and Humanities (POCARIM): Work Package 4: Survey Results Report. Liverpool: The University of Liverpool.

Larner. W. 2015. “Globalising knowledge networks: Universities, diaspora strategies, and academic intermediaries." Geoforum 59: 197-205.

Latour, B. 1993. We Have Never Been Modern. Cambridge, MA: Harvard University Press.

Latour, B. 1999a. “For David Bloor ... and Beyond: A Reply to David Bloor's 'Anti-Latour'." Studies in History and Philosophy of Science 30: 113-129.

Latour, B. 1999b. Pandora's Hope: Essays on the Reality of Science Studies. Cambridge, MA: Harvard University Press.

Lefebvre, H. 1991. The Production of Space. Translated by D. Nicholson-Smith. Oxford: Blackwell.

Leung, M. W. H. 2012. “'Read Ten Thousand Books, Walk Ten Thousand Miles': Geographical Mobility and Capital Accumulation among Chinese Scholars." Transactions of the Institute of British Geographers 38 (2): 311-324.

Madge, C., P. Raghuram, and P. Noxolo. 2015. “Conceptualizing International Education from International Student to International Study." Progress in Human Geography 39 (6): $681-701$.

Li, F. L. N., A. M. Findlay, A. J. Jowett, and R. Skeldon. 1996. “Migrating to Learn and Learning to Migrate: A Study of the Experiences and Intentions of International Student Migrants." International Journal of Population Geography 2 (1): 51-67.

Massey, D. 1991. “A Global Sense of Place.” Marxism Today (June): 24-29.

Millard, D. 2017. “Blended and Co-Existing Worlds in Intersectoral Mobilities of European PhD Graduates in the Social Sciences and Humanities." Globalisation, Societies and Education, in press 
Murray, F. 2010. "The Oncomouse that Roared: Hybrid Exchange Strategies as a Source of Distinction at the Boundary of Overlapping Institutions." American Journal of Sociology $116(2): 341-388$.

Prazeres, L. 2016. “Challenging the Comfort Zone: Self-Discovery, Everyday Practices and International Student Mobility to the Global South." Mobilities, in press: doi10.1080/17450101.2016.1225863

Raghuram, P. 2013. "Theorising the Spaces of Student Migration." Population, Space and Place 19 (2): 138-154.

Rienties, B., D. Luchoomun, and D. Tempelaar. 2014. "Academic and Social Integration of Master Students: A Cross-Institutional Comparison between Dutch and International Students." Innovations in Education and Teaching International 51 (2): 130-141.

Robertson, R. 1992. Globalization: Social Theory and Global Culture. London: Sage. Robertson, S. L. 2010. “Critical Response to Special Section: International Academic Mobility." Discourse: Studies in the Cultural Politics of Education 31 (5): 641-647.

Robertson, S. L., K. Olds, R. Dale, and Q. A. Dang, eds. 2016. Global Regionalisms and Higher Education: Projects, Processes, Politics. Cheltenham: Edward Elgar.

Robinson, W. I. and Harris, J. 2000. "Towards a Global Ruling Class? Globalization and the Transnational Capitalist Class." Science \& Society 64 (1): 11-54.

Saxenian, A. 2006. The New Argonauts: Regional Advantage in a Global Economy. Cambridge, MA: Harvard University Press.

Smith, M. P., and A. Favell, A., eds. 2006. The Human Face of Global Mobility: International Highly Skilled Migration in Europe, North America and the Asia-Pacific. New Brunswick: Transaction. 
Soja, E. W. 1996. Thirdspace: Journeys to Los Angeles and Other Real-and-Imagined Places. Oxford: Blackwell.

Storme, T., J. R. Faulconbridge, J. V. Beaverstock, B. Derudder, and F. Witlox, F. 2016.

"Mobility and Professional Networks in Academia: An Exploration of the Obligations of Presence." Mobilities 12 (3): 405-424.

Swyngedouw, E. 1992. “The Mammon Quest: 'Glocalization', Interspatial Competition and the Monetary Order: The Construction of New Scales." In Cities and Regions in the New Europe: The Global-Local Interplay and Spatial Development Strategies, edited by M. Dunford, and G. Kafkalis, 39-67. London: Belhaven Press.

Tournés, L., and G. Scott-Smith 2017. Global Exchanges: Scholarships and Transnational Circulations in the Modern World. Oxford: Berghahn Books.

Urry, J. 2007. Mobilities. Cambridge: Polity Press.

Van Mol, C. 2014. Intra-European Student Mobility in International Higher Education Circuits: Europe on the Move. Basingstoke: Palgrave Macmillan.

Van Riemsdijk, M. 2014. “International Migration and Local Emplacement: Everyday PlaceMaking Practices of Skilled Migrants in Oslo, Norway." Environment and Planning A 46 (4): 963-979.

Van Riemsdijk, M., and Q. Wang. (2016). Rethinking International Skilled Migration. New York: Routledge.

Waters, J. L. 2006. "Geographies of Cultural Capital." Transactions of the Institute of British Geographers 31 (2): 179-192. 
Waters, J. L. 2012. “Geographies of International Education: Mobilities and the Reproduction of Social (Dis)advantage." Geography Compass 6 (3): 123-136.

Waters, J. L., and M. Leung 2013. "Immobile Transnationalisms? Young People and Their In Situ Experiences of 'International' Education in Hong Kong." Urban Studies 50 (3): 606-620.

Zierhofer, W. 1999. “Geographie der Hybriden.” Erdkunde 53 (1): 1-13. 


\section{Tables}

Table 1. Identifying research perspectives on academic mobilities through triadic thought

\begin{tabular}{|c|c|c|c|c|}
\hline $\begin{array}{l}\text { Academic } \\
\text { practice }\end{array}$ & $\begin{array}{l}\text { Type of } \\
\text { actants }\end{array}$ & Materialities & Dynamic hybrids & Immaterialities \\
\hline \multirow{3}{*}{ Research } & & Books & People & Ideas \\
\hline & & Samples & Organisms & Feelings \\
\hline & & Infrastructures & Robots & Knowledge \\
\hline \multirow{3}{*}{ Teaching } & & Resources & Performances & Content \\
\hline & & Settings & Interactio ns & Approach \\
\hline & & Sites & Engagement & Emotions \\
\hline \multirow{3}{*}{ Learning } & & Notes & Students & Imaginations \\
\hline & & Drawings & Teachers & Knowledge \\
\hline & & Equipment & Colleagues & Skills \\
\hline
\end{tabular}

Source: Author's design based on Jöns 2003, 9, 147; Harvey 2005, 105; Jöns, Heffernan, and Meusburger 2017, 5. 
Table 2. Comparing research perspectives on academic mobilities through triadic thought

\begin{tabular}{lccc}
\hline $\begin{array}{c}\text { Career } \\
\text { stage }\end{array}$ & Early & Mid & Late \\
$\begin{array}{l}\text { Scale of } \\
\text { empirical approach }\end{array}$ & & \\
\hline Local & Findlay et al. & Gunter \& Raghuram & \\
Regional & King \& Sondhi & Coey & \\
Global & & Cillard & \\
\hline
\end{tabular}

Source: Author's design. 
Table 3. Conceptualising typical knowledge mobilities through relational triadic thought

\begin{tabular}{|c|c|c|c|}
\hline $\begin{array}{l}\begin{array}{r}\text { Direction of } \\
\text { movement }\end{array} \\
\text { Duration of } \\
\text { stay }\end{array}$ & $\begin{array}{l}\text { Linear } \\
\mathrm{A} \rightarrow \mathrm{B}\end{array}$ & $\begin{array}{l}\text { Circular } \\
\mathrm{A}\end{array}$ & $\begin{array}{l}\text { Reciprocal } \\
\qquad A \leftrightarrow B\end{array}$ \\
\hline Short-term & Internship & Academic travel & Commuting \\
\hline Medium-term & Degree mobility & Credit mobility & Transnationalism \\
\hline Long-term & Career migration & Return migration & Diaspora \\
\hline
\end{tabular}

Source: Author's design based on Jöns 2003, 9; Fielding 2012, 5. A and B designate different places of work, education, and/or residence.

\footnotetext{
' I am grateful to Russell King for asking a question after my paper at the $1^{\text {st }}$ International Conference on Geographies of Migration and Mobility (iMigMob) in Loughborough in July 2016 that alerted me to this ontological difference between the triads I had discussed. This helped me to develop my argumentation for the RGS-IBG Annual International Conference in August 2016, and in this article.

ii Triadic thought is represented, for example, by the sign/interpretant/object triad developed in semiotics (Latour 1993); by three-world-theories of Karl Popper (Zierhofer 1999) and Edward Soja (1996); and even by the Christian doctrine of the holy trinity, which conceptualizes one god in three forms (Jöns 2003, 148). The 'trinity of actants' also resembles in some ways the triad of material space (experienced space)/representations of space (conceptualized space)/spaces of representation (lived space) that Harvey $(2005,105)$ derived from Lefebvre's (1991) deliberations about the nature of space. Yet, in Harvey's (2005) understanding, lived space is not linked to the agency of humans, organisms, and robots but to people's feelings, fantasies, and frustrations. Yet, if reordered and redefined, the terms material/lived/conceptual space would capture the three ontologically different realms of the trinity of actants rather well.

iii The POCARIM research project illustrates that large scale collaborative projects may struggle to create comparable surveys for all participating countries due to sampling issues, low response rates, and other challenges. Although the POCARIM online survey from 2013 comprised of very different sampling strategies across the 13 European partner countries (Kupiszewska et al. 2013), in eleven countries it was possible to produce distributed survey samples of SSH PhD graduates from several universities, i.e. from 8-9 institutions in the smaller countries of Hungary and Latvia and from 14-27 universities in the larger countries. Yet, the country samples for the UK and Switzerland were not comparable with the other survey samples, which has prevented further, but in fact very interesting, comparative survey analyses as yet (Jöns and Deakin 2014, 13). The UK sample included responses from 22 universities, but $78 \%$ of these survey responses were from the University of Warwick-33\% from its Business School-, while the responses from the nine Swiss universities clustered at the Universities of Lausanne (64\%) and Lugano (19\%).
} 